Małgorzata Pagacz USJK ${ }^{1}$

ORCID: 0000-0003-4504-9142; mmpagacz@gmail.com

Akademia Katolicka w Warszawie

\title{
Modlitwa szkołą nadziei \\ w życiu osób konsekrowanych według Benedykta XVI
}

\section{Streszczenie}

Artykuł przedstawia zagadnienie modlitwy osób konsekrowanych na podstawie nauczania Benedykta XVI. Według papieża, modlitwa - która stanowi o istocie życia osób całkowicie poświęconych Bogu - jest pierwszym ważnym miejscem uczenia się nadziei opartej na Bogu i Jego obietnicach. Osoby konsekrowane pełnią posługę nadziei, ponieważ więź z Chrystusem i życie duchowe są dla nich czymś fundamentalnym. Poprzez swoje życie oddane modlitwie i kontemplacji rzeczy Bożych wskazują, gdzie odnawia się i oczyszcza wiara oraz ufność. Modlitwa osób konsekrowanych wyraża ofiarę składaną przez nich Bogu; jako znak nadziei ma niezastąpione znaczenie we współczesnym świecie.

Słowa kluczowe: życie konsekrowane, modlitwa, nadzieja, Benedykt XVI, duchowość

\section{Abstract}

Prayer as a School of Hope in the Life of Consecrated Persons According to Benedict XVI

The article presents the issue of prayer in the life of consecrated persons according to the teaching of Benedict XVI. According to the Pope, prayer - which is the essence of life of the people totally devoted to God - is the first important setting for learning hope, hope based on God and His promises. Consecrated persons are ministers of hope, because the relationship with Christ and the spiritual life are for them something fundamental. Their life, fulfilled with prayer and contemplation of God's matters shall show, where and how faith and trustfulness are renewed and

1 Małgorzata Pagacz USJK - dr, należy do Zgromadzenia Sióstr Urszulanek Serca Jezusa Konającego, teolog duchowości, mgr matematyki (Uniwersytet Jagielloński), wykładowca, odpowiedzialna za formację profesek czasowych swego Zgromadzenia. 
practiced. The prayer of consecrated persons expresses the total sacrifice to God. Being a sign of hope, it is of irreplaceable significance in the contemporary world.

Keywords: consecrated life, prayer, hope, Benedict XVI, spirituality

Benedykt XVI w encyklice Spe salvi nie obawia się pisać o współczesnym kryzysie chrześcijańskiej nadziei ${ }^{2}$. W obliczu stwierdzonego problemu pojawia się pytanie o możliwości i sposoby przezwyciężenia tego kryzysu. Zgodnie z nauczaniem Benedykta XVI pierwszym ważnym miejscem uczenia się nadziei jest modlitwa. Niniejszy artykuł ma na celu ukazanie, w jakim sensie modlitwa - należąca do istoty każdej formy życia konsekrowanego - stanowi szkołę nadziei w życiu osób poświęconych Bogu. Uzasadnia zarazem, że osoby konsekrowane, dla których więź z Chrystusem i życie duchowe są czymś fundamentalnym, stają się dla wszystkich znakami nadziei - wskazującymi, gdzie odnawia się i oczyszcza wiara i ufność - oraz sługami nadziei, którzy niosą ją innym.

\section{Modlitwa jako miejsce uczenia się nadziei}

Nadzieja chrześcijańska jako cnota teologalna jest darem łaski Boga, ale zarazem wymaga pielęgnowania. Według Benedykta XVI każdemu wierzącemu potrzebne jest odnawianie nadziei, czuwanie, by nie została ona zatracona czy przysłonięta przez problemy i trudności. Papież podkreśla, że kto chce żyć nadzieją, ma się w niej ćwiczyć, a pierwszym istotnym miejscem uczenia się nadziei jest modlitwa - szkoła nadziei ${ }^{3}$. W swej encyklice Spe salvi Benedykt XVI rozwija i uzasadnia tę myśl, która w pewnej mierze była już obecna w refleksji teologicznej Josepha Ratzingera.

Papież Benedykt XVI pokazuje, w jaki sposób modlitwa jest przestrzenią otwartą dla wszystkich, którym wydaje się, że tracą nadzieję. Jeśli ktoś doświadcza boleśnie, że już nikt go nie słucha, Bóg zawsze jest Tym, który jest gotowy słuchać i słucha. Do Niego można się zwracać, zawsze można Go wzywać:

2 Zob. Benedykt XVI, Encyklika Spe salvi (dalej: SS), 17, Kraków 2007.

3 Zob. SS 32. 
Jeśli nie ma już nikogo, kto mógłby mi pomóc - tam, gdzie chodzi o potrzebę albo oczekiwanie, które przerastają ludzkie możliwości trwania w nadziei - On może mi pomóc ${ }^{4}$.

Człowiek modlący się nie jest sam, nie jest pozostawiony sobie. Benedykt XVI przywołuje myśl świętego Augustyna, dla którego modlitwa jest miejscem ćwiczenia pragnień i dlatego otwiera na perspektywę nadziei. Człowiek w rzeczywistości pragnie Boga, gdyż dla Niego został stworzony. Jednak serce ludzkie jest zbyt ciasne, aby mogło przyjąć Stwórcę i pozostaje niespokojne dopóki w Nim nie spocznie $e^{5}$. Konieczny jest więc proces poszerzania serca tak, aby było ono zdolne dać miejsce Temu, dla którego zostało przeznaczone. Jest to możliwe jedynie wtedy, gdy człowiek pozwoli Bogu w sobie to uczynić. Bóg potrafi zwiększyć pojemność serca człowieka, powiększa jego pragnienia i nadzieję ${ }^{6}$. Równocześnie modlitwa ma moc zmiany pragnień, uczynienia ich prawdziwszymi i szlachetniejszymi, bardziej oderwanymi od siebie ze względu na kogoś Innego.

Zdaniem Benedykta XVI, serce trzeba nie tylko poszerzać, ale także oczyszczać. Modlitwa jest miejscem wzrostu nadziei, dlatego że stanowi proces niezbędnego i bolesnego oczyszczania wewnętrznego - otwiera modlącego się na Boga i na ludzi. To doświadczenie zazwyczaj połączone jest z cierpieniem, gdyż w ten sposób dusza człowieka może być przysposobiona do tego, do czego jest przeznaczona. Autentyczne spotkanie z Bogiem sprawia, że człowiek staje się wolny dla Boga i wrażliwy na innych. W modlitwie musi on oczyszczać swoje pragnienia i nadzieje, musi uczyć się przezwyciężać swój egoizm - nie może koncentrować się na sobie i ulegać małej, fałszywej nadziei, która oddala go od Boga i od bliźnich. Benedykt XVI zauważa:

Tak dokonują się w nas oczyszczenia, dzięki którym otwieramy się na Boga i stajemy się zdolni do służby ludziom. Tak też otwieramy się na wielką nadzieję i stajemy się sługami nadziei wobec innych: nadzieja w sensie chrześcijańskim jest też zawsze nadzieją dla innych? .

\footnotetext{
SS 32.

Zob. Święty Augustyn, Wyznania, I. 1, tłum. Z. Kubiak, Kraków 2004, s. 25.

Zob. SS 33.

SS 33.
} 
Jest wiele osób w Kościele, które doświadczyły, jak bardzo modlitwa daje rosnącą siłę nadziei, zwłaszcza w sytuacjach trudnych, granicznych, a dzieląc się tym własnym przeżyciem i odkryciem mogą nieść nadzieję także innym. Benedykt XVI w encyklice Spe salvi przywołuje jako przykład kardynała Nguyena van Thuana, który od 1975 roku spędził 13 lat w więzieniu w komunistycznym Wietnamie (bez wcześniejszego procesu i wyroku), w tym 9 lat w odosobnieniu ${ }^{8}$. Nocami w miejscu swego uwięzienia, zanim jeszcze znalazł się w izolowanej celi, spisywał swe refleksje, by utwierdzać wiernych w wierze i budzić w nich nadzieję. Te krótkie myśli, pisane na skrawkach papieru, były przemycane z więzienia przez małego chłopca, który odwiedzał van Thuana9. Biskup napisał między innymi:

Osoba, która żyje nadzieją, jest człowiekiem modlitwy. Przedmiot nadziei jest także przedmiotem modlitwy. Osoba, która żyje nadzieją jest współpracownikiem Boga.

Bóg wzywa ją, by dopełnić swego dzieła stworzenia i zbawienia ${ }^{10}$.

Nguyen van Thuan, dzięki modlitwie i zachowaniu nadziei w sytuacji skrajnie trudnej, po uwolnieniu mógł stać się dla ludzi całego świata świadkiem nadziei - „tej wielkiej nadziei, która nie gaśnie nawet podczas nocy samotności"11.

Według Benedykt XVI, aby modlitwa mogła być szkołą nadziei, z jednej strony powinna być bardzo osobista (konfrontująca ,ja” człowieka z Bogiem żywym), a z drugiej strony „musi być wciąż od nowa prowadzona i oświecana przez wielkie modlitwy Kościoła i świętych, przez modlitwę liturgiczną, w której Pan nieustannie uczy nas, jak modlić się właściwie"12. Podobnie Katechizm Kościoła katolickiego naucza, że uprzywilejowaną przestrzenią doskonalenia się nadziei jest liturgia. Duch Święty prowadzi i wychowuje uczestniczących w liturgii do modlitwy w nadziei ${ }^{13}$. Psalmy, które stanowią znaczącą część liturgii godzin,

8 Zob. SS 32.

Zob. F.X. Nguyen van Thuan, Drogi nadziei, Katowice-Ząbki 2002, s. 232.

10 F.X. Nguyen van Thuan, Drogi nadziei, s. 220.

11 SS 32.

12 SS 34.

13 Zob. Katechizm Kościoła katolickiego, Poznań 1994 (dalej: KKK), nr 2657. 
w sposób szczególny uczą zakorzenienia nadziei w Bogu, „dzięki swemu konkretnemu i zróżnicowanemu językowi" ${ }^{14}$. Za psalmistą wyznajemy: „Złożyłem w Panu całą nadzieję; On schylił się nade mną i wysłuchał mego wołania" (Ps 40, 2). Liturgia jest przestrzenią nadziei, bo stanowi odbicie wieczności.

Przywoływany przez Benedykta XVI kardynał Nguyen van Thuan akcentuje szczególne znaczenie Eucharystii jako szkoły nadziei. Nazywa on Ciało i Krew Pana pokarmem na „Drodze Nadziei”:

Ufaj tylko jednej sile: Eucharystii, która daje życie. „Ja przyszedłem po to, aby owce miały życie i miały je w obfitości” (J 10,10). Jak manna była pokarmem Izraelitów podczas podróży do Ziemi Obiecanej, tak Eucharystia jest twoim pokarmem na Drodze Nadziei ${ }^{15}$.

Podobnie o Eucharystii jako sakramencie nadziei ${ }^{16}$ naucza św. Jan Paweł II, który w encyklice Ecclesia de Eucharistia stwierdza, że Eucharystia „daje [...] impuls i pozwala nam z żywą nadzieją spełniać nasze codzienne zadania i obowiązki" ${ }^{17}$, natomiast w adhortacji apostolskiej Ecclesia in Europa pokazuje, że z Eucharystii jako z pokarmu pielgrzymujący Kościół czerpie wszelką nadzieję ${ }^{18}$.

Warto zauważyć, że nauczanie o modlitwie jako szkole nadziei jest już wyraźnie obecne w myśli teologicznej Josepha Ratzingera. W jednej ze swoich refleksji stwierdza on, że modlitwa jest realizującą się nadzieją:

14 KKK 2657.

15 F.X. Nguyen van Thuan, Nadzieja nie zawodzi. Refleksje w świetle Pisma świętego i dokumentów soborowych, Katowice-Ząbki 2002, s. 114.

16 Zob. E. Richer, Siła nadziei, Warszawa 1999, s. 34.

17 Jan Paweł II, Encyklika Ecclesia de Eucharistia, 20, Watykan 2003.

18 Zob. Jan Paweł II, Adhortacja apostolska, Ecclesia in Europa, 75, Watykan 2003. Eucharystia jest sakramentem nadziei paschalnej, gdyż stanowi zadatek przyszłej chwały. Wierzący mogą być przekonani, że komunia z Jezusem, którą przeżywają jako pielgrzymi w życiu doczesnym, daje im przedsmak ostatecznego spotkania w dniu, w którym będą do Niego podobni, bo ujrzą Go takim, jakim jest (zob. 1 J 3, 2). „Eucharystia jest doczesnym przedsmakiem wieczności, jest Boską obecnością i komunią z nią; jako pamiątka Paschy Chrystusa z samej swej natury wnosi w ludzkie dzieje łaskę. Otwiera na Bożą przyszłość; będąc komunią z Chrystusem, z Jego ciałem i krwią, jest uczestnictwem w życiu wiecznym Boga" (Jan Paweł II, Adhortacja apostolska Ecclesia in Europa, 75). 
Człowiek zrozpaczony przestaje się modlić; człowiek pewien samego siebie i swoich sił nie modli się, gdyż ufa jedynie samemu sobie. Ten, kto się modli, pokłada nadzieję w dobroci i mocy, które przekraczają jego możliwości. Modlitwa jest realizującą się nadzieją ${ }^{19}$.

Modlitwa jest koniecznym wsparciem dla nadziei. Nie można wejść w świat nadziei, jeśli nie wejdzie się w przestrzeń modlitwy. Kardynał Ratzinger zauważa, że św. Tomasz w Sumie teologicznej twierdzi, iż modlitwa jest interpretacją nadziei ${ }^{20}$, jest językiem nadziei. Formuła zakończenia modlitw liturgicznych: „Przez Chrystusa, Pana naszego” opiera się na prawdzie, że Chrystus jest zrealizowaną nadzieją, kotwicą ludzkiej nadziei. Według Akwinaty doskonałą szkołą nadziei i jej konkretnym początkiem jest modlitwa „Ojcze nasz”. W niej codzienne obawy i niepokoje mają szansę przemienić się w nadzieję ${ }^{21}$.

Ten, kto się modli, nie pozbawia się nadziei oraz wskazuje także innym, że jest jeszcze nadzieja, nie wszystko stracone. Sługami nadziei są i powinni być więc wszyscy chrześcijanie.

Modlitwa ukazuje nam prawdziwą przyczynę naszej nadziei, a jeśli modlitwa doprowadzi nas do odkrycia, że to Bóg jest tą skuteczną przyczyną, zrozumiemy, jak ratuje ona jednocześnie ludzkie zakorzenienie naszych pragnień i naszej nadziei, a nawet nieskończenie więcej: jedynie ona czyni to możliwe i realne. Nie tylko ocala ona Boga w nas, ale ratuje ona także człowieka ${ }^{22}$.

Modlitwa pełni niezastąpioną rolę w umacnianiu i ożywianiu chrześcijańskiej nadziei i ufności wobec Boga.

Według Benedykta XVI modlitwa jest szkołą nadziei, jest ćwiczeniem pragnienia, miejscem oczyszczania dążeń i nadziei. Aby mogła ona pełnić tę funkcję, powinna być jak najbardziej osobista, odzwierciedlać więź z żywym Bogiem, a równocześnie musi być wspomagana i oświecana przez modlitwę liturgiczną. Tak jak miłość i wiara, by były żywe, muszą być ciągle umacniane i podtrzymywane przez ofiarny dar z siebie

19 J. Ratzinger, Patrzeć na Chrystusa, tłum. J. Merecki, Kraków 2005, s. 61.

20 Zob. J. Ratzinger, Patrzeć na Chrystusa, s. 60-61.

21 Zob. J. Ratzinger, Patrzeć na Chrystusa, s. 60-62.

22 F. Philippe, Aby nie stracić nadziei, tłum. M. Krzeptowska, Kraków 1997, s. 58. 
i przez postawę zawierzenia, podobnie nadzieja wzrasta, gdy znajduje swój odpowiedni wyraz, a dzieje się to w sposób uprzywilejowany w autentycznym życiu modlitwy.

O pewnych aspektach modlitwy w perspektywie umacniania nadziei mówi posoborowe nauczanie Kościoła (KKK; św. Jan Paweł II). Jednak dopiero papież Benedykt XVI akcentuje i rozwija myśl o modlitwie jako pierwszym istotnym miejscu uczenia się nadziei chrześcijańskiej. Równocześnie widać ciągłość tej koncepcji z jego wcześniejszą refleksją teologiczną, którą podejmował przed wyborem na papieża. Warto także zauważyć, że wizja modlitwy jako szkoły nadziei jest również obecna u autorów niechrześcijańskich. Przykładowo Abraham Joshua Heschel stwierdza:

Modlitwa oczyszcza nasze intencje i nadzieje. Odsłania prawdziwe dążenia, wydobywa na wierzch spychane na bok wyrzuty sumienia, ujawnia zapomniane tęsknoty. To kwarantanna duszy ${ }^{23}$.

Spojrzenie na modlitwę jako szkołę nadziei, jakie prezentuje Benedykt XVI, wydaje się szczególnie cenne w obecnych czasach, które naznaczone są kryzysem nadziei ${ }^{24}$. Współczesny człowiek często jest zagubiony, przygnieciony problemami, czuje się rzucony w istnienie czy doświadcza pustki egzystencjalnej. Szybkiemu postępowi naukowemu i technicznemu nie towarzyszy rozwój w sferze ducha. Papież Franciszek potwierdza tę diagnozę: s. 40.

A.J. Heschel, Prositem o cud. Antologia duchowej mądrości, tłum. A. Gomola, Poznań 2001,

${ }_{24}$ Zob. SS 17. „Jednym z najbardziej ponurych i niepokojących aspektów współczesnej kultury, a zwłaszcza kultury zachodniej, jest brak jakiejkolwiek w niej nadziei. Ludzkość zdaje się być pogrążona w niepokoju, strachu i w nieustannej trosce o własne przeżycie: niesprawiedliwych wojen, podziałów wśród narodów, coraz większego uzbrojenia, prawie nieodwracalnego ubóstwa wielu krajów, zminimalizowanej uwagi przykładanej do poczucia solidarności ze słabymi i potrzebującymi, wzrastającego bezrobocia, kultury masowej, klęsk ekologicznych, rozprzestrzeniających się coraz groźniejszych chorób zakaźnych, narkomanii, a zwłaszcza szerzenia się jej wśród młodzieży" (Jezus Chrystus, jedyny Zbawiciel świata, wczoraj, dziś i na wieki, Oficjalny dokument Papieskiego Komitetu Obchodów Wielkiego Jubileuszu Roku 2000, Katowice 1996, s. 184-185). 
Lęk i rozpacz opanowują serce wielu osób, nawet w tak zwanych bogatych krajach. Często gaśnie radość życia, wzrasta brak szacunku i przemoc, nierówność społeczna staje się coraz bardziej oczywista. Trzeba walczyć, aby żyć i często żyć bez poszanowania swej godności ${ }^{25}$.

W takiej sytuacji naglące staje się szukanie dróg wyjścia.

\section{Modlitwa i posługa nadziei osób konsekrowanych}

Modlitwa jest szczególnie dana i zadana osobom konsekrowanym, których życie jest całkowicie poświęcone Bogu. Osoby będące własnością Boga odczytują zaproszenie, by iść drogą naśladowania i upodabniania się do Jezusa Chrystusa. Chrześcijańska nadzieja opiera się na pewności, że tylko w Chrystusie jest prawdziwe życie, zarówno w przyszłości, jak też w teraźniejszości. Życie konsekrowane wyraża najgłębszą istotę powołania chrześcijańskiego i ukazuje dążenie całego Kościoła-Oblubienicy do zjednoczenia z jedynym Oblubieńcem. Podtrzymuje i ożywia w Kościele posługę świętości, wzywając wierzących, by bardziej dostosowywali się do wymagań Jezusa i Ewangelii niż do oczekiwań otoczenia. Zakonnik, oddając się modlitwie, czuwa i wyczekuje spełnienia się obietnic Chrystusa, a tym samym umie natchnąć nadzieją także swoich braci i siostry, często zniechęconych i pesymistycznie patrzących w przyszłość.

Przeznaczając znaczną część swego dnia na spotkanie z Bogiem, osoby konsekrowane mają sposobność, aby osobiście doskonalić się w nadziei oraz świadczyć o niej wobec innych i pokazywać im, gdzie jej szukać. Powołane do modlitwy - nie tylko w swoich intencjach, ale całego Kościoła i świata - stają się wyraźnymi znakami nadziei. Benedykt XVI, nauczając w encyklice Spe salvi o modlitwie jako miejscu szukania nadziei i ćwiczenia się w niej, wyznacza zarazem rolę i znaczenie modlitwy konsekrowanych. Ponadto w wielu homiliach i przemówieniach do osób poświęconych Bogu rozwija tę myśl i wzywa zakonników do dawania świadectwa nadziei właśnie poprzez ich życie duchowe i troskę o żywą relację z Bogiem.

25 Franciszek, Adhortacja apostolska Evangelii gaudium, 52, Częstochowa 2013. 
Benedykt XVI naucza osoby zakonne o zadaniu, jakie mają do wypełnienia:

Modląc się i poszcząc, stajecie się orędownikami tych, którzy szukają Boga, którzy są w drodze do Boga. Dajecie świadectwo nadziei, która wbrew wszelkiej niemej lub jawnej rozpaczy wskazuje na wierność i pełną miłości troskę Boga. Dzięki temu jesteście z tymi wszystkimi, którzy uginają się pod ciężarem losu i nie potrafią uwolnić się od jego jarzma. Dajecie świadectwo tej Miłości, która oddaje się za ludzi i w ten sposób zwyciężyła śmierć ${ }^{26}$.

Papież wypowiadział te słowa, odwiedzając siostry klaryski - mniszki klauzurowe mieszkające na „Farmie nadziei”, które służą dziełu pomocy osobom próbującym przezwyciężyć problemy związane z uzależnieniem od narkotyków, alkoholu i środków chemicznych. Mówił zakonnicom, że istotnie poprzez swą posługę miłości głoszą, że nadzieja zawieść nie może oraz pomagają odnaleźć utraconą nadzieję. Siostry klauzurowe czynią to „poprzez cichą, ofiarną modlitwę, wymowną ciszę, której słucha Ojciec"27. Ich misja niesienia nadziei ma szczególne znaczenie w miejscu, do którego przybywa wielu ludzi, którzy utracili już nadzieję. Klaryski i wszystkie osoby poświęcone Bogu w wiernej modlitwie, w uwielbieniu Stwórcy i Zbawiciela mają za zadanie głosić „przesłanie miłości, która zwycięża ból, narkotyki i śmierć” ${ }^{28}$, wyznawać Jezusa Chrystusa, który wziął na siebie grzechy ludzkie, aby wszystkich od nich uwolnićs ${ }^{29}$.

Modlitwa osób poświęconych Bogu ma wyrażać całkowitą ofiarę z życia składaną przez nich Bogu. Benedykt XVI zwraca się do konsekrowanych:

26 Benedykt XVI, Przemówienie do duchowieństwa, osób konsekrowanych i seminarzystów w Mariazell Iść za Chrystusem znaczy przyswajać sobie Jego styl życia, 8.09.2007, w: Benedykt XVI do osób konsekrowanych, red. M. Saj, Kraków 2009 [dalej: BdOK], s. 149-150.

27 Benedykt XVI, Przemówienie podczas spotkania z klaryskami w czasie podróży apostolskiej do Brazylii Poprzez cicha, ofiarna modlitwę głoście przesłanie miłości, która zwycięża ból, nałóg i śmierć, 12.05.2007, w: BdOK, s. 132.

${ }_{28}$ Benedykt XVI, Przemówienie podczas spotkania z klaryskami w czasie podróży apostolskiej do Brazylii, s. 132.

${ }_{29}$ Zob. Benedykt XVI, Przemówienie podczas spotkania z klaryskami w czasie podróży apostolskiej do Brazylii, s. 132; M. Pagacz, Życie konsekrowane znakiem nadziei dla współczesnego świata w nauczaniu Kościoła od Soboru Watykańskiego II, Kraków 2019, s. 328. 
Sami staniecie się żywymi ołtarzami, na których ofiarna miłość Chrystusa uobecnia się jako natchnienie i źródło duchowego pokarmu dla każdego napotkanego przez was człowieka ${ }^{30}$.

Modlitwa osób zakonnych jest również szczególnym wyrazem pragnienia Boga i nadziei pokładanej w Nim. Nadzieja chrześcijańska nie jest bowiem tylko tęsknotą za niebem, ale żywym i czynnym pragnieniem Boga w tym świecie - pragnieniem Boga, które sprawia, że człowiek jest niestrudzonym pielgrzymem ${ }^{31}$. Papież Benedykt XVI zaznacza, że zakonnicy są dla wszystkich prorockim znakiem królestwa niebieskiego, a ich życie ma profetyczną wartość dla dzisiejszego świata ${ }^{32}$. Żyją oni w swoich czasach, ale ich serce wybiega poza czas. Ich całkowite oddanie się w ręce Chrystusa i Kościoła jest mocnym i wyraźnym głoszeniem obecności Boga w języku zrozumiałym dla współczesnych ludzi ${ }^{33}$. Niesienie proroczego świadectwa światu nie jest pozbawione zmagań i trudu. Dlatego osoby konsekrowane są wezwane do wierności modlitwie, zaufania prawdzie Ewangelii i pokładania niezłomnej nadziei w obietnicach Boga.

Według Benedykta XVI, uprzywilejowaną przestrzenią nadziei jest liturgia, która stanowi odbicie wieczności. Papież przekonuje osoby konsekrowane, że dostrzeganie w liturgii - całkowicie skupionej na Bogu - w obrzędach i pieśniach obrazu wieczności nie jest przesadą ani zuchwalstwem, lecz wyrazem istoty liturgii. Ci, którzy są poświęceni Bogu na własność przez zaangażowanie w modlitwę brewiarzową mają skierowywać spojrzenie swoje i innych ku Bogu, gdyż właśnie przed Nim

30 Benedykt XVI, Przemówienie na spotkaniu z duchowieństwem w Sydney Bądźcie znakiem odnowy dla ludu Bożego, 19.07.2008, w: BdOK, s. 250.

31 Zob. Benedykt XVI, Homilia w uroczystość Wniebowzięcia Najświętszej Maryi Panny Kiedy otwieramy się na Boga, nasze życie staje się bogate i wielkie, 15.082012, „L'Osservatore Romano" wydanie polskie (dalej: ORpol.) 9-10 (2012), s. 32.

32 Zob. Benedykt XVI, Homilia podczas Nieszporów w święto Ofiarowania Pańskiego Życie konsekrowane świadectwem umiłowania Ewangelii, 2.02.2011, ORpol. 3 (2011), s. 27.

33 Zob. Benedykt XVI, Przemówienie do osób konsekrowanych diecezji rzymskiej Kościół i świat potrzebują Waszego świadectwa, 10.12.2005, w: BdOK, s. 47; Benedykt XVI, Homilia w święto Ofiarowania Pańskiego Nieoceniony dar życia konsekrowanego, 2.02.2006, w: BdOK, s. 55; Benedykt XVI, Do wiernych Kościoła katolickiego w Republice Chińskiej Powołania i formacja zakonna, 27.05.2007, w: BdOK, s. 144. 
stają i do Niego się zwracają. Teocentryczne nastawienie osób konsekrowanych w liturgii jest warunkiem koniecznym do tego, by one i ich modlitwa były czytelnymi znakami wielkiej nadziei opartej na Bogu. Najlepiej obmyślone i przygotowane plany, zmierzające do upiększenia, uatrakcyjnienia liturgii czy uczynienia jej bardziej interesującą, nie tylko są zbyteczne, ale ponadto odsuwają od tego, co najważniejsze. Bóg ma być podmiotem liturgii, gdyż jest ona „opus Dei”. Jedynie liturgia sprawowana w ukierunkowaniu na Boga i skupieniu na Nim, w komunii ze świętymi ma moc umocnić prawdziwą nadzieję $e^{34}$.

Oddawanie chwały Bogu w modlitwie i liturgii to zasadnicza i niezastąpiona posługa zakonników dla świata, która zarazem jest posługą ożywiania nadziei. Jeśli chcą oni być wierni Bogu i powołaniu, nie mogą uchylać się od realizacji słów św. Benedykta znajdujących się w napisanej przez niego regule: „Niczego nad służbę Bożą nie przedkładać” ${ }^{35}$. Papież Benedykt XVI, zwracając się do osób konsekrowanych, wielokrotnie przywołuje to napomnienie świętego z Nursji. Zaznacza, że uwielbienie, wychwalanie i wysławianie Pana Boga sprawia, że „na ziemi uobecnia się trochę nieba" ${ }^{36}$. Można także ufać, że tam, gdzie wiernie adoruje się Boga, nie zabraknie Jego błogosławieństwa. Papież zapewnia, że regularne odmawianie brewiarza, choć wymaga dyscypliny i czasami jest niemałym wysiłkiem woli, często przynosi pocieszenie, usuwa zmęczenie czy przygnębienie oraz pozwala na nowo popatrzeć z nadzieją w przyszłość. Dokonuje się to mocą Ducha Świętego, który przychodzi z pomocą ludzkiej słabości - kiedy człowiek nie umie się modlić, On przyczynia się za wierzącymi w błaganiach, których nie można wyrazić słowami (zob. Rz 8, 26) ${ }^{37}$.

Każda modlitwa liturgiczna jest przede wszystkim uwielbieniem Boga, ponieważ On i tylko On jest godzien uwielbienia. Jednocześnie oficjum osób konsekrowanych stanowi świętą służbę ludziom oraz świadectwo

34 Zob. Benedykt XVI, Przemówienie w opactwie cystersów w Heiligenkreuz Niczego nad stużbę Bożą nie przedkładać, 9.09.2007, w: BdOK, s. 163; M. Pagacz, Życie konsekrowane znakiem nadziei, s. 328-329.

35 Benedykt XVI, Przemówienie w opactwie cystersów w Heiligenkreuz, s. 163.

36 Benedykt XVI, Przemówienie w opactwie cystersów w Heiligenkreuz, s. 163.

37 Zob. Benedykt XVI, Przemówienie w opactwie cystersów w Heiligenkreuz, s. 162-163. 
nadziei dla nich. Benedykt XVI zauważa, że każdy człowiek w głębi swego serca odczuwa tęsknotę - za którą niekiedy nie ma odwagi podążać i nawet nie zawsze ją sobie uświadamia - za ostatecznym zaspokojeniem, za największym szczęściem, a więc w istocie za samym Bogiem. Modlitwa zakonników - zwłaszcza wspólnotowe uwielbienie Stwórcy i Odkupiciela - stanowi świadectwo, że to fundamentalne pragnienie ludzkie nie trafia w pustkę, że nadzieja ma swoje spełnienie. Osoby konsekrowane ukazują, że

Bóg nie pozostawia nas na pustyni nicości, pozbawionej sensu, gdzie ostatecznie czeka na nas tylko śmierć. Nie! Bóg rozjaśnił nasze mroki swoim światłem za sprawą swego Syna Jezusa Chrystusa. W Nim Bóg wkroczył w nasz świat z całą swą Pełnią (zob. Kol 1, 19). W Nim każda prawda, za którą tęsknimy, ma swoje źródło i szczyt ${ }^{38}$.

Przykład modlitwy osób oddanych Bogu może natchnąć nadzieją tych wszystkich, którzy jej szukają i potrzebują; co więcej - ukazuje, kto w rzeczywistości jest źródłem niezawodnej nadziei.

Zakonnicy i zakonnice, zwłaszcza z klasztorów kontemplacyjnych, poprzez ciągłą i wspólnotową modlitwę wstawiają się nieustannie za całą ludzkością. Fakt ten jest wystarczającym powodem, by nie tracić nadziei, nawet w trudnych i zmiennych okolicznościach życia ${ }^{39}$. Benedykt XVI zauważa, że w tradycji monastycznej ojcowie Kościoła określali mnichów jako tych, którzy prowadzą życie na wzór aniołów, ponieważ tych ostatnich wyróżnia adoracja. Życie zakonników ma być więc nieustanną adoracją - tak jak jest nią egzystencja aniołów - i nade wszystko uwielbieniem Boga, jak zachęcają słowa psalmu: „Wysławiajcie Pana, bo jest dobry, bo Jego łaska trwa na wieki” (Ps 107, 1). Modlitwa ta nie ma konkretnego celu, lecz chce być czystą służbą Bożą, którą można określić - w pełnym znaczeniu tego słowa - „świętą służbą”. „Ofiarowana jest ona Bogu Trójjedynemu, który ponad wszystko jest godzien «odebrać chwałę i cześć, i moc» (Ap 4,11), ponieważ

38 Benedykt XVI, Przemówienie w opactwie cystersów w Heiligenkreuz, s. 160-161; M. Pagacz, Życie konsekrowane znakiem nadziei, s. 330.

39 Zob. Benedykt XVI, Orędzie na 45. Światowy Dzień Modlitw o Powołania Powołania w służbie Kościoła misyjnego, 13.04.2008, ORpol. 3 (2008), s. 7. 
w cudowny sposób stworzył świat i w sposób jeszcze bardziej cudowny go odnowił"40 - zaznacza papież.

Modlitwa osób konsekrowanych, będąca uwielbieniem Boga, jest przestrzenią odnawiania i umacniania prawdziwej nadziei, opartej na Bogu i Jego obietnicach. Osoby zakonne, znajdujące się w samym sercu Kościoła, we wspólnotach o decydującym znaczeniu dla jego misji, są tymi, które we współczesnym świecie mają stanowić znak prawdziwej nadziei opartej na Bogu.

Zgodnie z nauczaniem Benedykta XVI modlitwa osób konsekrowanych jest miejscem uczenia się nadziei i świadectwem nadziei dzięki absolutnemu pierwszeństwu, które zakonnicy przyznają w swoim życiu Bogu. I odwrotnie: prymat Boga, znajdujący swój wyraz w modlitwie osób poświęconych Bogu, czyni z życia konsekrowanego znak nadziei. Kto poddaje całą swoją egzystencję Trójjedynemu Bogu i kieruje się pragnieniem wypełniania Jego woli, wskazuje, że On jest źródłem nadziei i niezawodnym oparciem. Benedykt XVI ukazuje więc życie zakonne przede wszystkim jako znak prymatu Boga - spośród wielu wymiarów życia konsekrowanego kładzie nacisk właśnie na ten aspekt. Co więcej, zagadnienie konieczności przyznania pierwszeństwa Bogu to jedna $\mathrm{z}$ najistotniejszych kwestii stale poruszanych przez papieża ${ }^{41}$. Według Benedykta XVI,

pierwszym i najwyższym dążeniem zakonników powinno być świadczenie o tym, że Boga należy słuchać i miłować z całego serca, z całej duszy, ze wszystkich sił, dając Mu pierwszeństwo przed wszystkimi innymi osobami i rzeczami ${ }^{42}$.

Wszystkie klasztory i domy zakonne mają stanowić miejsca „preferencji Boga"43, a będzie to możliwe jedynie dzięki wierności modlitwie i trosce o oddawanie chwały Najwyższemu.

Papież Benedykt XVI zaleca konsekrowanym modlitwę ułożoną przez św. Ignacego z Loyoli, założyciela Towarzystwa Jezusowego, która wyraża

Benedykt XVI, Przemówienie w opactwie cystersów w Heiligenkreuz, s. 160.

${ }^{41}$ Zob. J. Szymik, Theologia Benedicta, t. 1, Katowice 2010, s. 161-185; R. Sarah, N. Diat, Bóg albo nic. Rozmowa o wierze, tłum. A. Kuryś, Warszawa 2016, s. 145-149.

42 Benedykt XVI, Przemówienie do osób konsekrowanych diecezji rzymskiej, s. 44.

43 Zob. Benedykt XVI, Przemówienie w opactwie cystersów w Heiligenkreuz, s. 164. 
postawę zaufania i zawierzenia Bogu oraz zawiera w sobie istotę posłuszeństwa woli Bożej, posłuszeństwa miłości. Nie ukrywa, że modlitwa ta może wydawać się zbyt wielka - człowiek do niej nie dorasta. Jednak łaska Boża sprawia, że zakonnik jest w stanie szukać, znajdować, a następnie wypełnić wolę miłującego Boga, w którym całkowicie pokłada nadzieję. Papież zachęca osoby konsekrowane, by wciąż na nowo - choć być może z trudem - odmawiały ją, próbując według niej kształtować swoje życie, mówiąc:

Zabierz, Panie, i przyjmij całą moją wolność, pamięć moją, mój rozum i całą moją wolę, wszystko, co mam i co posiadam. Ty mi to, Panie, dałeś, Tobie to zwracam. Wszystko jest Twoje. Rozporządzaj tym, według Twojej woli. Daj mi tylko miłość Twoją i łaskę, a to mi wystarczy, o nic więcej nie proszę (Ćwiczenia duchowne, nr 234) $)^{44}$.

Modlitwa ta jest prośbą o zespolenie woli Bożej z wolą ludzką, a zarazem pokazuje nadzieję na połączenie woli Boga z wolą człowieka.

Osoby konsekrowane z modlitwy czerpią siły, aby pełnić posługę niesienia nadziei. Benedykt XVI przypomina, że życie konsekrowane poprzez różnorodne formy działalności, łącząc aktywność z życiem modlitwy, ma pełnić misję ożywiania nadziei u ludzi. Posłannictwo to jest udziałem wszystkich chrześcijan, którzy powinni głosić moc zmartwychwstania zwłaszcza tam, gdzie nie widzi się już żadnej przyszłości ani nadziei ${ }^{45}$. Osoby konsekrowane mają szczególny obowiązek pielęgnowania nadziei w sobie i w innych. Papież wzywa je:

Wasze życie niech będzie jak zaczyn, który zakwasza całą mąkę (zob. Mt 13, 33), niekiedy ciche i ukryte, ale zawsze twórcze i dodające otuchy, zdolne budzić nadzieje ${ }^{46}$.

Miejsca pełnienia apostolatu przez konsekrowanych są zróżnicowane, jednak każde działanie osób konsekrowanych powinno podnosić

${ }_{44}$ Benedykt XVI, Przemówienie do duchowieństwa, osób konsekrowanych i seminarzystów w Mariazell, s. 156.

${ }_{45}$ Benedykt XVI, Przemówienie podczas spotkania z klaryskami w czasie podróży apostolskiej do Brazylii, s. 129.

46 Benedykt XVI, Przemówienie podczas Międzynarodowego Sympozjum Instytutów Świeckich Bądźcie w świecie ewangelicznym zaczynem, 3-4.02.2007, w: BdOK, s. 110. 
na duchu, wskazywać, gdzie szukać nadziei, jak jej nie utracić i jak ją podtrzymywać ${ }^{47}$. Misja ta może być owocna jedynie wówczas, gdy zakorzeniona jest w ufnej modlitwie i głębokim życiu duchowym. Oparcie się na Bogu jest konieczne, aby podejmowane aktywności miały sens.

Osoby konsekrowane pełnią posługę nadziei, o ile przede wszystkim same ufają w Bożą Opatrzność i trwają w modlitwie zawierzenia miłości Boga. W ten sposób umocnione mogą wychodzić naprzeciw codziennym wydarzeniom oraz wyzwaniom życia, nie dając się ponieść lękowi o przyszłość, która także im częstokroć wydaje się po ludzku mroczna i przerażająca. Zakonnicy są wezwani do dawania świadectwa, że Bóg Jezusa Chrystusa, który wszedł w ludzką historię, aby mogła osiągnąć swoje ostateczne spełnienie, jest Alfą i Omegą, początkiem i końcem (zob. Ap 1,8$)^{48}$. Osoby konsekrowane nie mogą tracić nadziei: czerpiąc moc z modlitwy, mają przezwyciężać zniechęcenie, a przez każde swe działanie świadczyć, że Pan Bóg udziela gwarancji, iż

w każdym, choćby małym, lecz szczerym uczynku miłości zawiera się cały sens wszechświata, i że ten, kto nie waha się stracić swojego życia z Jego powodu, odnajdzie je w pełni (zob. Mt 16, 25) ${ }^{49}$.

Modlitwa osób konsekrowanych pozwala im widzieć wszystko w świetle wiary, która jest darem Boga.

Z nauczania Benedykta XVI wynika, że jednym ze znaków nadziei jaśniejących na horyzoncie współczesności jest życie konsekrowane, które może wnieść zaufanie w możliwość nadziei zakorzenionej w Bogu. Papież nie zaprzecza trudnościom, z którymi muszą się zmagać osoby konsekrowane. Przestrzega zarazem, aby nie przyłączać się do proroków nieszczęścia, którzy głoszą kres lub bezsensowność życia konsekrowanego w Kościele obecnych czasów, lecz zachęca, by przyoblec się w Jezusa Chrystusa $^{50}$.

47 Zob. M. Pagacz, Życie konsekrowane znakiem nadziei, s. 361.

${ }_{48}$ Zob. Benedykt XVI, Nie lękajmy się przyszłości. Niedzielna modlitwa z Papieżem, 18.11.2007, w: BdOK, s. 172.

49 Benedykt XVI, Nie lękajmy się przyszłości, s. 172.

50 Zob. Benedykt XVI, Homilia podczas Mszy św. w święto Ofiarowania Pańskiego Wiara potrafi rozpoznać mądrość słabości, 2.02.2013, ORpol. 3-4 (2013), s. 21. 


\section{Zakończenie}

Reasumując, kontemplacja rzeczy Bożych oraz ustawiczne zjednoczenie z Bogiem to zasadniczy cel egzystencji osób poświęconych Bogu. Modlitwa zajmuje niezastąpione miejsce w ich życiu. Dla nich samych jest ona przestrzenią nieustannego oczyszczania i poszerzania serca, by w nim było więcej miejsca dla Boga, oraz odnawiania w sobie nadziei pośród różnych ludzkich problemów i przeciwności. Benedykt XVI podkreśla ponadto znaczenie przykładu modlitwy i nadziei, jakie dają innym osoby poświęcone Bogu. Ci, którzy się modlą dają na zewnątrz świadectwo obecnej w nich teologalnej nadziei, a ci, którzy doświadczyli, jak bardzo modlitwa wzmacnia ludzką siłę, dzięki nadziei pokładanej w Bogu - zwłaszcza w sytuacjach trudnych - własnym świadectwem mogą nieść nadzieję innym. Konsekrowani są w sposób szczególny sługami nadziei we współczesnym świecie, w którym jest wiele zniechęcenia i braku poczucia sensu. Dają wyraz tego, jak należy trwać w oczekiwaniu, wiedząc, że tego, czego się oczekuje, nie można przyspieszyć, lecz musi przyjść to od Boga. Ich wytrwałość w modlitwie jest warunkiem stałości w nadziei, zgodnie ze słowami św. Pawła: „Weselcie się nadzieją! W ucisku bądźcie cierpliwi, w modlitwie wytrwali” (Rz 12, 12). W swoim nauczaniu Benedykt XVI pokazuje, że życie osób konsekrowanych jest przeniknięte chrześcijańską nadzieją. Ta forma życia całkowicie poświęconego Bogu nie jest możliwa do zrozumienia z wykluczeniem cnót teologalnych. Zwłaszcza w dzisiejszych czasach, gdy ludzka nadzieja jest zagrożona i gaśnie, osoby konsekrowane powołane są szczególnie do dawania świadectwa teologalnej nadziei, pochodzącej od Boga. Modlitwa konsekrowanych ma niezrównane znaczenie dla świata.

Życie konsekrowane przeniknięte duchem modlitwy daje przykład Bożej nadziei we współczesnym świecie. Nie jest ono nadzieją, nie jest jej źródłem. Stanowi natomiast znak tej nadziei, czyli wskazuje, że właściwa nadzieja znajduje się jedynie w Bogu. Osoby konsekrowane są jak światła, które nie świecą swym własnym światłem - źródłem światła jest Chrystus, jedyna nadzieja. Zakonnik, oddający się adoracji i uwielbieniu Boga, jest drogowskazem, który pokazuje kierunek, lecz nie zniewala sobą. Jest powołany, aby patrzeć w przyszłość z nadzieją, budzić nadzieję, pociągać 
ku dobru i pocieszać. Dzięki sile, którą czerpie z modlitwy indywidualnej i wspólnotowej, może iść tam, gdzie nadzieja jest szczególnie potrzebna i docierać do osób odrzuconych, zagubionych, zniechęconych i zrozpaczonych. Posługa ta będzie owocna o tyle, o ile będzie trwał w Bożej miłości, będąc wierny modlitwie, zapominając o sobie i stawiając w centrum żyjącego Chrystusa.

\section{Bibliografia}

Augustyn z Hippony, Wyznania, tłum. Z. Kubiak, Kraków 2004.

Benedykt XVI, Do wiernych Kościoła katolickiego w Republice Chińskiej Powołania i formacja zakonna, w: Benedykt XVI do osób konsekrowanych, red. M. Saj, Kraków 2009, s. $141-144$.

Benedykt XVI, Encyklika Spe salvi, Kraków 2007.

Benedykt XVI, Homilia w święto Ofiarowania Pańskiego Nieoceniony dar życia konsekrowanego, w: Benedykt XVI do osób konsekrowanych, red. M. Saj, Kraków 2009, s. 49-55.

Benedykt XVI, Homilia podczas Nieszporów w święto Ofiarowania Pańskiego Życie konsekrowane świadectwem umiłowania Ewangelii, ORpol. 3 (2011), s. 27.

Benedykt XVI, Homilia w uroczystość Wniebowzięcia Najświętszej Maryi Panny Kiedy otwieramy się na Boga, nasze życie staje się bogate i wielkie, ORpol. 9-10 (2012), s. 31-32.

Benedykt XVI, Homilia podczas Mszy św. w święto Ofiarowania Pańskiego Wiara potrafi rozpoznać madrość słabości, ORpol. 3-4 (2013), s. 19-21.

Benedykt XVI, Nie lękajmy się przyszłości. Niedzielna modlitwa z Papieżem, w: Benedykt XVI do osób konsekrowanych, red. M. Saj, Kraków 2009, s. 169-173.

Benedykt XVI, Orędzie na 45. Światowy Dzień Modlitw o Powołania Powołania w służbie Kościoła misyjnego, ORpol. 3 (2008), s. 7.

Benedykt XVI, Przemówienie do duchowieństwa, osób konsekrowanych i seminarzystów w Mariazell Iść za Chrystusem znaczy przyswajać sobie Jego styl życia, w: Benedykt XVI do osób konsekrowanych, red. M. Saj, Kraków 2009, s. 145-156.

Benedykt XVI, Przemówienie do osób konsekrowanych diecezji rzymskiej Kościót $i$ świat potrzebuja Waszego świadectwa, w: Benedykt XVI do osób konsekrowanych, red. M. Saj, Kraków 2009, s. 41-47.

Benedykt XVI, Przemówienie na spotkaniu z duchowieństwem w Sydney Bądźcie znakiem odnowy dla ludu Bożego, w: Benedykt XVI do osób konsekrowanych, red. M. Saj, Kraków 2009, s. 241-251.

Benedykt XVI, Przemówienie podczas Międzynarodowego Sympozjum Instytutów Świeckich Bądźcie w świecie ewangelicznym zaczynem, w: Benedykt XVI do osób konsekrowanych, red. M. Saj, Kraków 2009, s. 103-112.

Benedykt XVI, Przemówienie podczas spotkania z klaryskami w czasie podróży apostolskiej do Brazylii Poprzez cicha, ofiarna modlitwę głoście przesłanie miłości, która 
zwycięża ból, nałóg i śmierć, w: Benedykt XVI do osób konsekrowanych, red. M. Saj, Kraków 2009, s. 127-132.

Benedykt XVI, Przemówienie w opactwie cystersów w Heiligenkreuz Niczego nad służbę Bożą nie przedkładać, w: Benedykt XVI do osób konsekrowanych, red. M. Saj, Kraków 2009, s. 157-168.

Franciszek, Adhortacja apostolska Evangelii gaudium, Częstochowa 2013.

Heschel A.J., Prositem o cud. Antologia duchowej mądrości, tłum. A. Gomola, Poznań 2001.

Jan Paweł II, Adhortacja apostolska Ecclesia in Europa, Watykan 2003.

Jan Paweł II, Encyklika Ecclesia de Eucharistia, Watykan 2003.

Jezus Chrystus, jedyny Zbawiciel świata, wczoraj, dziś i na wieki. Oficjalny dokument Papieskiego Komitetu Obchodów Wielkiego Jubileuszu Roku 2000, Katowice 1996.

Katechizm Kościoła katolickiego, Poznań 1994.

Kłoczowski J.A., Rekolekcje o nadziei, Kraków 2005.

Łuźniak A., Struktura nadziei w ujęciu św. Augustyna, w: Oblicza chrześcijańskiej nadziei, red. W. Irek, Wrocław 2008, s. 47-60.

Nguyen van Thuan F.X., Drogi nadziei, tłum. J. Chapska, Katowice-Ząbki 2002.

Nguyen van Thuan F.X., Modlitwy nadziei, tłum. P. Pindur, Katowice 2007.

Nguyen van Thuan F.X., Nadzieja nie zawodzi. Refleksje w świetle Pisma Świętego i dokumentów soborowych, tłum. J. Chapska, Katowice-Ząbki 2002.

Oblicza nadziei, red. M. Worbs, Opole 2008.

Pagacz M., Życie konsekrowane znakiem nadziei dla współczesnego świata w nauczaniu Kościoła od Soboru Watykańskiego II, Kraków 2019.

Philippe F., Aby nie stracić nadziei, tłum. M. Krzeptowska, Kraków 1997.

Pismo Święte Starego i Nowego Testamentu, Poznań 2002.

Ratzinger J., Patrzeć na Chrystusa, tłum. J. Merecki, Kraków 2005.

Sarah R., Diat N., Bóg albo nic. Rozmowa o wierze, tłum. A. Kuryś, Warszawa 2016.

Szymik J., Theologia Benedicta, t. 1, Katowice 2010.

Urbański S., Nadzieja w modlitwie chrześcijańskiej, w: Nadzieja w postawie ludzkiej, red. W. Słomka, Lublin 1992, s. 167-202. 